\title{
Mining Heritage and Mining Tourism
}

\author{
Jakub Jelen \\ e-mail: jakub.jelen@natur.cuni.cz
}

Department of Social Geography and Regional Development, Faculty of Science,

Charles University, Prague, Czech Republic

Jelen, J. (2018). Mining Heritage and Mining Tourism. Czech Journal of Tourism, 7(1), 93-105. DOI: 10.1515/cjot-2018-0005.

\begin{abstract}
The mining industry leaves behind a large number of tangible or intangible remains. A part of them can be used by different actors as a mining heritage. Specific cultural or social values and meanings, which remind of the importance of mining in the past and today, are represented through this mining heritage. To preserve them, the heritage must be passed to future generations. One of the ways is mining tourism. However, the relation between the mining heritage and tourism is not simple as the complex mining heritage has many specific features that differ from the traditional tourist attractions and conceal many pitfalls. The aspects of authenticity or approaches to heritage interpretation are also important.
\end{abstract}

\section{Keywords:}

mining heritage, mining tourism, interpretation, development

JEL classification: L83 


\section{Introduction}

In recent years, there has been a trend, for at least a part of society, to move away from mass tourism and towards more individual experiences or cultural tourism. This is primarily concerned with investigating history, cultural heritage, traditions, customs, and way of life of those living in the visited destination. Cultural tourism presupposes the visitors' readiness to discover and acquire new information and combines leisure time with education. The participants' aim is to discover a new cultural heritage, its values, implications and influences on society. Kadlec and Svoboda (2007) define 'heritage tourism' as a sub-branch of cultural tourism.

Cultural tourism began to emerge in the last two decades of the twentieth century, for reasons including the transition from an industrial to a post-industrial society linked with the transformation of economy, the development of new technologies, and changes in the employment structure (Kadlec \& Svoboda, 2007). This socio-economic transformation produced a rich spectrum of cultural heritage relating to the industrial era, including heavy and mining industries. The mining of mineral wealth was (and still is) a prominent developmental factor in many areas, employing large numbers of people and giving rise to a specific mining culture. However, the process of de-industrialisation and the subsequent transformation of mining areas is proceeding very rapidly, with mines closing at short notice. They are, however, a very important element in the development of society and should not be completely erased from memory. Indeed, vanishing remains could be treated as part of our heritage that help preserve its values and meaning. Cultural tourism is one way of ensuring that it is preserved and passed on to a wider audience and to future generations.

The aim of this article is to discuss the role of mining heritage in tourism as part of our cultural heritage and at the same time, the role of tourism in the protection, interpretation, and preservation of this kind of heritage. It will also consider the potential and risks of the development of one partial branch of tourism, mining tourism, and discuss the role of authenticity and interpretation as tools for the presentation and dissemination of values and meanings linked with the mining heritage.

\section{Approaches to the research issue}

\section{Mining heritage as part of cultural heritage}

Many fields of science deal with studies of heritage, its definitions, categorisation or exploitation from conservation, historiography, culturology, and tourism point of view as an independent field of heritage studies (e.g., Raistrick, 1972; Kudrnáč, 1999; Conlin \& Jolliffe, 2014). The definition of heritage itself is very difficult because it always depends on the writer's point of view, particularly in terms of delimitation. Heritage can be understood as a complex of material and non-material elements and phenomena created by cultural memory and perception of the past by people in a certain context. It includes relics of the past, actively processed and used in the present (Smith, 2006; Harvey, 2008). 
Heritage offers the representation of values and meanings supporting the significance of places and feelings of community solidarity (Smith, 2006; Urry, 1990). It refers to notable objects, persons, events, or opinions or relations in a cultural context of the given period (Holtorf, 2002). The creation of heritage is a dynamic socio-cultural process and within its bounds there are inevitably conflicts and discrepancies between individuals, groups, and institutions from the point of view of perceptions of what should or should not be considered as heritage and how it should be treated. Heritage changes over the course of time, attitudes towards a possible change, and values and meanings may be re-interpreted or even disappear. In coming into contact with heritage, its users and recipients create their own personal values and identities (Smith, 2006). In the broadest interpretation, almost anything people decide to protect could be considered as heritage (Hewison, 1989; Howard, 2003) and thus it is possible to perceive it in a rather attitudinal way (Ashworth \& Tunbridge, 1996; Graham et al., 2000; Harvey, 2001). On the one hand, it is up to each individual what he or she considers as heritage and what specific values he or she assigns to it, but it also depends on the whole society, its principles and rules. Every heritage can be used by various participants for various purposes. This is also linked to problems with its interpretation because it can be perceived and read in different or contradictory ways. Thus, heritage is often seen as a difficult or arduous task (Ashworth \& Tunbridge, 1996).

Cultural heritage is also defined by legal documents, international treaties, and national documents. It can be either conventions at international (UNESCO, ICOMOS) or national (laws of national states, authorities of monument care) level. The most important international document is the Convention on the Protection of the World Cultural and Natural Heritage, approved by the UNESCO General Conference in Paris in 1972, which defines what can be considered as heritage (cultural, natural, or mixed) (Kučová, 2009). At the national level, the cultural heritage is in various ways listed in the laws of different countries. In the Czech Republic, it is primarily the National Monuments Act, which deals with preservation of monuments. This law says that the heritage can be considered as a monument, i.e., it mentions primarily the material nature of the heritage. The intangible nature reflects the above-mentioned Convention implemented in the Czech legal order. The law definition of inheritance serves primarily the authorities of the National Monument Conservation, which focuses on its inventory, protection, and preservation.

Through heritage it is possible to pass on and construct a wide spectrum of values and meanings relating to many aspects of human activities. In addition, the production of food and basic activities include the mining and processing of mineral resources, which can be reliably traced back to prehistory (Karel \& Kratochvílová, 2013). The whole eras of human history are named after the predominant mineral resources extracted and exploited (the Bronze or Iron Ages). With the gradual development of science and technology, humans delved ever deeper into the earth and discovered new resources and new ways to process and use them. At the same time, people were improving mining technologies and extracting increasing quantities of materials. However, mining leaves extensive residues, it transforms landscapes and societies and once mining activity ends, 
there is always the question of what to do with these complex remains (Conesa, Schulin, \& Nowack, 2008). The mining industry is considered an important sector, but the material remains from the mining activities (particularly from the industrial era) were for a long time seen as unattractive features of the landscape and efforts to remove any traces of mining were more common than preserving and making use of them (Fragner \& Zikmund, 2009). Such remains do, however, often exhibit historical and cultural values linked to our forebears' technological achievements and abilities and the lives of mining communities, their traditions, habits, or religions (Tomíšková, 2011). When looking at the mining remains as heritage, there are clear contradictions which relate primarily to the definition of heritage values, but also to the economic and environmental risks connected with their use. There was already a debate about the preservation of industrial and mining remains and their subsequent management in the second half of the twentieth century, when disciplines such as industrial and mining archaeology were established and developed (Blažková \& Matoušek, 2013). There was a changing perception of industrial complexes and they were coming to be seen as heritage elements needing to be protected and opened to the public. The organisation of international conferences on heritage matters and the founding of the International Committee for the Conservation of the Industrial Heritage (TICCIH) also show a growing interest in these issues on the part of experts (Blažková \& Matoušek, 2013; Jelen \& Kučera, 2017). The remains of mining and the processing of mineral resources that are used to represent and interpret the values and issues linked to the mining industry and mineworkers can therefore be labelled as mining heritage (Mazáč, 2003; Loures, 2008, Jelen \& Kučera, 2017), which is part of cultural heritage as it refers to and interprets specific cultural, historical, and social values and meanings. It can be either material (pits, buildings, equipment, miners' uniforms) or immaterial (procedures, miners' habits, and traditions).

\section{The origins of the mining heritage and issues related to its use}

The mining industry was usually connected with development. Furthermore, miners brought specific knowledge and skills to regions, but also their own culture, tradition and religion. The closure of mines, however, brought stagnation and economic transformation. New business activities are sought to compensate for the loss of income from the mines. For example, the mining industry and its workings employed many people who might face the risk of unemployment following the closure of the pits. Moreover, the residues left by mining may conceal many dangers that limit their subsequent use (Coupland \& Coupland, 2014). Each mining region is characterised by the minerals mined there, the time and space that the mining took up and the technology used, but it is possible to identify certain common features and issues typical of the majority of mining regions. The most common and fundamental problem is the extensiveness of a given area, particularly in the case of opencast mining. However, even underground mining could take up vast surface areas for the storage of the extracted materials that are not then processed (gangue). The next danger is the environmental risk; the presence 
of heavy metals in the soil or water contaminated by mining run-off (Conesa, Schulin, \& Nowack, 2008). When mining ceases, large contaminated areas require specific treatment, for example, re-cultivation to redevelop contaminated surfaces and to disguise human intervention in the landscape, thus creating a completely new type of landscape for subsequent use. The goal of re-cultivation is to restore the environmental and aesthetic functions and the economic and recreational potential of areas left behind or devastated by human activity and to reintegrate them into the surrounding landscape (Štýs, 1990). This is a complicated process but its goal should not be to completely erase all traces of mining from the landscape and to create the illusion that mining never took place there. It is important to conserve substantial elements of the heritage of mining and the miners, creating a real mining heritage. However, there are many remnants left by mining and it is not possible or even appropriate to incorporate all of them into the heritage. A selection of representative elements and the identification of their specific cultural or other values and meanings is required in order to preserve, protect, and further interpret them for the public. These are the tasks of the conservation authorities and expert institutions, as well as of voluntary associations and non-governmental organisations dealing with the mining remains (Stefanovová \& Lednický, 2012). The remnants of mining activities are integral parts of the post-industrial and post-mining landscape and require further protection and focus as they are evidence of both the mining and the cultural, social, and environmental history of the regions (Schejbal, 2016). The heritage protection is an important stage in the process and is determined by many conditions, mostly set by laws or international conventions. The most important subject of conservation and heritage conservation is monumen conservatin. It works on a national and international scale, and its form and level are different in different countries of the world. In general, international organizations dealing with heritage protection are the United Nations Educational, Scientific and Cultural Organization (UNESCO) and the International Council for Monuments and Settlements (ICOMOS).

With regard to the recognition of the mining heritage, there is a question of how to present it and at the same time to interpret and pass it on in order to preserve and cultivate its specific values and meanings. The origin of the mining heritage is seen as a component of the area regeneration (economic and social) and it should be used appropriately. Many museums, open-air folk museums, and mines or galleries open to the public have come into existence. However, the mining landscape itself can also be seen as a mining heritage. The same is true for miners' festivals, processions, or mining bands (Jelen \& Kučera, 2017). One possible way to present this heritage to the public and ensure it is to use it as a tourist attraction within the realm of cultural tourism.

\section{Mining heritage as a tourist attraction}

Cultural tourism focused on the use of mining heritage, and the representation, protection, and interpretation of its values and meanings for visitors could be described as mining tourism (Schejbal, 2016) or also as a type of geotourism (Hose, 2005). Geotourism is 
different from mining tourism with its geological and geomorphologically focus (Hose, 2012). On the other hand, mining tourism is more focused on the remains of mining activities and mining heritage. According to Zelenka and Pásková (2002), those participating in mining tourism are drawn by the possibility of guided tours through the underground workings of former or even still functioning mines, their technical equipment and buildings. This, however, leaves out many components, particularly those of a less material nature, which can be considered as part of mining heritage, making the definition unsatisfactory. Schejbal (2017) offers a more complex explanation when he says that this is an independent discipline aimed at studying abandoned mining spaces, remains of mining activity, and mining heritage with the aim of preserving cultural-historical values and their use in tourism. This definition also echoes many foreign authors (e.g., Conlin \& Jolliffe, 2014; Cole, 2004; Coupland \& Coupland, 2014). Mining tourism can be considered as an important process that helps both to interpret the mining heritage and to serve as a subsequent source of employment and business activity following the end of mining. It is valued as a motivating force that can encourage the economic potential of the mining heritage and contribute to conserving it in a form that can generate income (Kadlec \& Svoboda, 2007). It can also have a multiplier effect, generally in the form of tourism, by linking up with other activities and operations of local participants and communities. In their publication Mining Heritage and Tourism, Conlin and Jolliffe (2014) provide many case studies from all over the world to demonstrate the possibilities of using the mining remains for tourism.

However, the relation between the mining heritage and tourism is not simple as the complex mining heritage has many specific features that differ from the traditional tourist attractions and conceal many pitfalls. One of the basic problems with the mining remains is that they are generally seen as unsightly and unattractive to tourists and there is a contradiction in even preserving them and investing in them to make them accessible. Conesa, Schulin, and Nowack (2008) indicate that mining heritage is less attractive because it is measured by a different beauty standard. However, this assertion is rebutted in the Czech Republic, for instance, by a long-term growth in the number of visitors to mining sights (Karel \& Kratochvílová, 2013; Urban, 2011). At the same time, there is an increased interest in their conservation as it has been proven by the nomination of 15 items of the mining heritage from all over the world proposed for designations as the UNESCO world heritage sites, as well as the several dozen mining heritage sites already included in the list (Schejbal, 2017; Jelen \& Chromý, 2018). The next difficulty lies in the fact that the mining localities tend to be relatively far from the traditional tourist paths and visiting them therefore requires a greater investment of both time and money. Another important element is the frequent difficult accessibility of underground spaces, which call for a certain level of health, physical fitness, and resilience on the part of visitors. However, these drawbacks can also work in the mining heritage's favour by reducing visitor numbers and thus preventing any over-touristification of these regions, which could damage the unique mining heritage (Zelenka \& Pásková, 2002). It is important to grasp the individuality and specific genius loci of the mining heritage sites; tourism should contribute to the conservation, preservation, and passing on of its values, 
rather than the heritage being produced for the needs of tourism. These factors mean that mining tourism will never become a mass attraction. It forms a specific circuit of visitors and thanks to them can also preserve its foundations.

In the creation of heritage, it is important to stress its integrity, the interconnectedness of elements and events, both material and non-material, that come together to create a complex whole. It is important to introduce and interpret not only material artefacts and buildings but also the non-material components, particularly the implications of the heritage for the present. An integral part of cultural tourism is its educational aspect. Mining always contributed to the development of learning in various fields because it was present at the discovery of many new chemical elements and minerals and it helped to describe phenomena and processes under the earth's surface. Thus, it is important to consider its contribution to geology, mineralogy, geonics, and other disciplines, as well as the societal level, i.e., miners and their communities. The mining of mineral resources is one of the most dangerous occupations and over centuries religion has played a significant role in miners' lives. The work is characterised by its close relationship to, reverence, and respect for nature. All of these values and meanings create a complex element of the mining heritage which needs to be presented as a whole since only then can it be preserved. The question is in what way and form this complex can be interpreted and presented to participants in mining tourism (e.g., Cohen, 1988; Boniface \& Fowler, 1993; Coupland \& Coupland, 2014).

\section{Results}

\section{The interpretation and authenticity of the mining heritage}

'What', i.e., what values are presented, and 'how', i.e., in what way this is done, are two important questions in the interpretation of heritage. The interpretation comes from the study of the values and features of the given heritage and serves to pass them on to the public, visitors, and future generations, thus participating in its conservation (Timothy \& Boyd, 2003). At the same time, it includes a risk of misinterpretation of certain meanings because the values of every heritage can be perceived, interpreted, and presented subjectively and in various ways (see arduous heritage, Ashworth \& Tunbridge, 1996; Smith, 2006). The process of interpretation has several basic elements (Ptáček \& Růžička, 2012; Ham \& Weiler, 2012). It is a creative activity and it should create a link with the given place for a visitor and provide an educational, emotional, or spiritual experience and at the same time, introduce and present the place in an original way (Nuryanti, 2005). It should aim to attract visitors, to surprise them, and to encourage them to think about the facts or implications (of places, buildings, or persons). The interpretation can take many forms and proceed in various ways, from a simple text description, an exhibition of various items, spoken word, an audio-visual projection to engagement of a visitor through interactive exhibits (Ptáček, 2004). The aim is not only to provide facts, but also to offer new perspectives and ways of understanding the given heritage (Jelen \& Kučera, 2017). Holistic approaches to interpretation planning are very 
important when it is necessary to introduce heritage as a functional complex, not only as a set of individual components (Wheeler, 2014). It is desirable to acquaint visitors with links and processes, not only material remnants. The heritage interpretation can help create a certain idea of them, and thus in the process of its cognition, it does not matter only what but primarily how and by whom it is interpreted (Ashworth \& Tunbridge, 1996; Smith, 2006). Kesner et al. (2008) introduce a five-point scale of interpretation tools and their impact on visitors' senses and perceptions of the things presented. The most fundamental is a simple description of facts (in a text or other form), which only has a passive effect on a visitor's perception. The second level is to present more variations and perspectives on the facts so that they can be compared and evaluated. The third level is explanation, giving reasons for the origin, links, theories, and facts, which a visitor can accept or reject. The next level consists of a narration or a story, which brings together all three of the above components but adds an emotional level because it is linked with a real person or group, allowing for a deeper experience of and empathy for the facts presented. Depending on the nature of an individual experience, this can lead a visitor to identify with the story they are presented. The final level is an experiment in which a visitor is allowed to experience tangible things so as to make sense of general assertions and to better understand contexts. The higher the level of presentation that is chosen, the greater is the possibility that issues will be remembered and the intended interpretation achieved. The high-quality interpretation and presentation do not only consist of retelling and description, but also of real communication with a visitor. If the process is successful, the visitor becomes more interested in the facts and can also acquire a greater respect and esteem for the heritage. This can arouse in a visitor a sense of responsibility for its perception and conservation and they may be drawn into active involvement in the process of heritage conservation. The selected method is fundamental to passing on the values and meanings of the heritage to the general public. At the same time, the high-quality interpretation fulfils the essence of cultural tourism because it elicits in a visitor an interest in learning and discovering, as well as providing information (Kesner et al., 2008).

A very important idea of the heritage interpretation is authenticity, i.e., the verifiability or originality of the facts presented, but there is also the question of whether it is even necessary to attempt to present heritage when, for instance, Baudrillard (1983) says that tourism prefers reconstructed objects to real ones, inclines towards imitations, and values a copy more than an original. Heritage can be stripped of its authenticity and degraded into a nostalgic attempt to idealise the past and thus to create a 'false history'. This can happen primarily if heritage is seen only as a set of artefacts serving merely to interpret history. In the late $1980 \mathrm{~s}$, the notion of the 'heritage industry' emerged in Great Britain to describe the commercialisation of the past. Heritage is commodified (it becomes a 'good') and is offered as a set of artefacts from the past, not linked to the problems of the present time (Wright, 1985). Museums and public institutions dealing with the past struggled to create an idea that restored a harmonic past which, however, never existed. This strategy aimed to create a tourist destination or a trademark able to attract visitors (González, 2015). Heritage thus became a way of presenting history 
to the public, an economic activity motivated by economic or political interests, and it became a marketable commodity used primarily for the needs of tourism (Chang, 2002). This ended up with a loss of the original meaning and essence. Approaches to heritage as a material commodity began to be criticised in the late 1980 s and early 1990 s. Hewison (1897) argues that the expansion of heritage as a form of popular entertainment distracted both experts and public from the perception of the essence of culture or art. He points out that a nostalgic escape into the past takes place instead of a critical delimitation of our relationship with it, and the heritage industry creates utopian images of the past, devoid of any associations. These critiques are also confirmed, for instance, by Lowenthal (1985, 1997).

Mining tourism presents an assorted range of mining heritage to the general public. Various mining museums, accessible pit galleries, or exhibitions of mining technologies are the most frequent examples. Visitors often expect an authentic underground environment, but the question of authenticity includes discussion of what the original conditions would be in theory. The mining heritage differs significantly from the traditional cultural sites of historical interest. Mine works are full of dust, dirt, noise, and potential danger. Miners do highly dangerous work and their time underground is subject to strict rules. There are tourist destinations that offer visitors the possibility to visit functioning mines, but these are rarities and visits are subject to strict safety precautions and other restrictions. The only example of such a tourist destination in Czechia is the Coal Safari (Uhelné safari), which allows visitors to inspect surface mines in the district of Most. Another attempt of an authentic presentation is the so-called last day exhibits, when an object or establishment is left as if miners left only a few minutes ago (e.g., a mining exhibition in Ostrava). This concept is often used in the case of surface buildings of former mines. Among the other typical Czech regions with the appearance of elements of the mining heritage, one can list the Ore Mountains (towns like Jáchymov, Horní Blatná, Cínovec, or Krupka) or the mentioned Ostrava region and also cities such as Příbram, Stříbro, Kutná hora, or Kladno.

Questions of authenticity can largely be solved by procedures first established in Great Britain but now widespread, where former miners are often employed as guides in newly opened mining exhibitions. This increases the potential for authenticity when minerguides describe visitors their own experiences with working in the mines. This approach has the added benefit of creating new work opportunities in places where mining has ceased, which tend to have a high unemployment rate. Miner-guides bring their own ambitions to passing on their heritage and thus support the development and conservation of a local mining community and identity. Tunbridge and Ashworth (1996) call these processes a "second life as heritage". Although miner-guides do not fully compensate for the original form of the mine works, they introduce an important component in the presentation and understanding of the mining heritage in their personal motivation, experience, and emotions. Telling stories or recounting their own experiences, they are able to take visitors back to the past, to recreate the specific genius loci of the place, and pass on values or meanings through their own identities and their relation to the things they present. This interpretation and passing on of their heritage is non-material rather 
than material in character. An important role is played by both individuals and local communities in preserving mining traditions or folklore thanks to their relationship to mining values, passing them on to future generations. These processes can compensate for the lesser authenticity of the physical environment because in passing on values and meanings in a non-material form, they contribute to a more deep-reaching conservation, building up a relation to the mining heritage that goes beyond its material essence (Coupland \& Coupland, 2014).

\section{Conclusion}

The mining heritage is a specific body of both material and immaterial components relating and representing values and meanings linked to the mining of mineral resources and to the miners and their communities. Mining is a significant process in the development of society but it is also a dangerous activity that requires technical skills, education, and knowledge of natural conditions. Mining communities are characterised by their relation to and respect for nature, their strong social links and a high level of religious observance. All these create a self-contained complex of values which are also significant for contemporary society and they deserve to be preserved for future generations.

The specific features of the mining heritage give it the potential to become a tourist attraction in relevant areas and this can offer a way to preserve it and pass it on to future generations. However, it is a very specific kind of tourism that attracts people interested in acquiring new information and facts and who are also ready to adapt to its particular conditions. Especially, the holistic approaches to planning the heritage interpretation in which the mining heritage is presented as a functioning complex rather than as a body of individual components are essential. It is important to show visitors the links and processes involved as well as the material remnants and artefacts. It is also essential to find a balance among all the heritage functions and not to focus only on some of them for the needs of tourism. The mining heritage can satisfy the needs of tourism, but it should not be subordinated to these and created purely to generate income. As with all areas of cultural tourism, the educational function is also very important. The essence of the heritage can only be seized if it is interpreted in a proper way. Using the example of the mining heritage, we can see that for authentic exhibitions it is essential to present historical, cultural, and social values through the identity of the place, the local inhabitants and the miners. These are naturally suited to this and such interpretations supplement the spatial and material framework created by physical exhibits. The fundamental component of a cultural heritage experience is a story mediating the authenticity of the place visited. A significant role in the presentation and interpretation is played by local museums, historic sites, and residents who are holders of stories linked with the cultural heritage. At the same time, the interpretation is a key to distinguishing between the places that favours the uniqueness, specific features, and characteristics of individual areas and in the commercial environment of tourism it can also offer a competitive advantage. The interpretation communicates contexts and serves to connect places with 
their history, to create an experience, and to arouse emotions through which a visitor can understand heritage values and even adopt these as their own.

\section{Acknowledgement}

This work was supported by the Czech Science Foundation under Grant no. P410/12/G113.

\section{References}

Ashworth, G., \& Tunbridge, J. E. (1996). Dissonant Heritage: The Management of the Past as a Resource in Conflict. Chichester: Wiley.

Baudrillard, J. (1983). Simulations. New York: Semiotext.

Blažková, T., \& Matoušek, V. (2013). Česká krajina 19. a 20. století ve světle industriální archeologie - stav bádání (Czech landscape of the 19th and 20th Centuries in the lamp of Industrial Archeology - Status of Research). In P. Vařeka (Ed.), Archeologie 19. a 20. stoleti (Archeology of the 19th and 20th centuries) (pp 17-22). Pilsen: University of West Bohemia in Pilsen.

Boniface, P., \& Fowler, P. J. (1993). Heritage and tourism in 'the global village'. London: Routledge.

Chang, T. C. (2002). Heritage as a Tourism Commodity: Traversing the Tourist-Local Divide. Singapore Journal of Tropical Geography, 18(1), 46-68. DOI: 10.1111/1467-9493.00004.

Cohen, E. (1988). Authenticity and commoditization in tourism. Annuals of Tourism Research, 15(1), 371-386. DOI: 10.1016/0160-7383(88)90028-X.

Cole, D. (2004). Exploring the Sustainability of Mining Heritage Tourism. Journal of Sustainable Tourism, 12(6), 480-494. DOI: 10.1080/09669580408667250.

Conesa, H. M., Schulin, R., \& Nowack, B. (2008). Mining landscape: A cultural tourist opportunity or an environmental problem? The study case of the Cartagena-La Unión Mining District (SE Spain), Ecological Economics, 64(4), 690-700. DOI: 10.1016/j.ecolecon.2007.06.023.

Conlin, M. V., Jolliffe, L. (2014). Mining Heritage and Tourism: A Global Synthesis. London and New York: Routledge.

Coupland, B., \& Coupland, N. (2014). The authenticating discourses of mining heritage tourism in Cornwall and Wales. Journal of Sociolinguistics, 18(4), 495-517. DOI: 10.1111/josl.12081.

Fragner, B., \& Zikmund, J. (2009). Co jsme si zborili. Bilance mizejicí průmyslové éry/deset let (What we have destroyed. The Balance of the Dying Industrial Age/Ten Years). Prague: ČVUT.

González, P. A. (2015). Conceptualizing Cultural Heritage as a Common. In P. F. Biehl, D. C. Comer, C. Prescott, \& H. A. Soderland (Eds.), Identity and Heritage, Contemporary Challenges in a Globalized World (pp. 27-35). London: Springer.

Graham, B., Ashworth, G., \& Tunbridge, J. E. (2000). A Geography of Heritage: Power, Culture, Economy. London: Arnold.

Ham, H. S., \& Weiler, B. (2012). Interpretation as the centrepiece of sustainable wildlife tourism. In R. Harris, T. Grrifin, \& P. Williams (Eds.), Sustainable Tourism: A Global Perspective (pp. 35-44). New York: Routledge.

Harvey, D. C. (2001). Heritage pasts and heritage presents: Temporality, meaning and the scope of heritage studies. International Journal of Heritage Studies, 7(4), 319-338. DOI: $10.1080 / 13581650120105534$.

Harvey, D. C. (2008). The History of Heritage. In B. Graham \& P. Howard (Eds.), The Ashgate Research Companion to Heritage and Identity (pp. 19-36). Aldershot: Ashgate. 
Hewison, R. (1987). The heritage industry: Britain in a climate of decline. Methuen: London.

Hewison, R. (1989). Heritage: An interpretation. In L. Uzzell (Ed.), Heritage Interpretation (pp. 15-23). London: Belhaven.

Holtorf, C. J. (2002). Monumental Past: The Life-histories of Megalithic Monuments in Mecklenburg-Vorpommern (Germany). Papers from the Institute of Archaeology, 13(1), 130-136.

Hose, T. A. (2005). Geotourism: Appreciating the deep time of landscapes. In M. Novelli (Ed.), Niche Tourism: Contemporary Issues, Trends and Cases (pp. 27-38). Oxford: Elsevier.

Hose, T. A. (2012). 3G's for Modern Geotourism. Geoheritage Journal, 4, 7-24. DOI: 10.1007/ s12371-011-0052-y.

Howard, P. (2003). Heritage: Management, Interpretation, Identity. London: Continuum.

Jelen, J., \& Kučera, Z. (2017). Dědictví (nejen) uranové těžby na Jáchymovsku. (Heritage (not only) of uranium mining in the Jáchymov region). Geografické rozhledy (Geographical views), 26(3), $28-30$.

Jelen, J., \& Chromý, P. (2018). Krušnohoří jako součást světového dědictví UNESCO? (Ore Mountains as part of UNESCO World Heritage?). Geografické rozhledy (Geographical views), 27(5), 3033.

Kadlec, M., \& Svoboda, M (2007). Památková péče, cestovní ruch a veřejná správa (Monument care, tourism and public administration). Prague: Ministry for Regional Development of Czech Republic. Retrieved from www.mmr.cz/getmedia/71687f46-21f8-4e70-8b5c-afb6ab19ad38/GetFile7_1. pdf.

Karel, T., \& Kratochvílová, A. (Eds.). (2013). Proměny montánni krajiny. Historické sídelni a montánní struktury Krušnohoř́ (Changes in the historical and mining landscape. Historic settlement and mining structures of the Ore Mountains). Loket: National Heritage Institute.

Kesner, L. Moravec, I., Novotný, R., \& Škodová-Parmová, D. (2008). Management kulturního cestovniho ruchu (Management of cultural tourism). Prague: Cultropa.

Kučová V. (2009): Světové kulturni a př́rodni dédictvi UNESCO (World Cultural and Natural Heritage by UNESCO). Prague: Národní památkový ústav (National Heritage Institute).

Kudrnáč, J. (1999). Montánní archeologie a geologie (Mining archeology and geology). Archeologické rozhledy (Archeological views), 51(1), 168-172.

Loures, L. (2008). Industrial heritage: The past in the future of the city. WSEAS Transactions on Environment and Development, 4(8), s. 687-696.

Lowenthal, D. (1985). The Past is a Foreign Country. Cambridge: Cambridge University Press.

Lowenthal, D. (1997). The Heritage Crusade and the Spoils of History. Cambridge: Cambridge University Press.

Mazáč, J. (2003). Technické kulturni památky (Technical cultural monuments). Ostrava: VŠB - Technical University of Ostrava.

Nuryanti, W. (2005). The role of interpretation in ecotourism develoment. The Indonesian Institute of the Arts (pp. 112-119).

Ptáček, L., \& Rủžička, T. (Eds.). (2012). Jak předkládat svět: základy dobré interpretace (How to Present the World: The Basics of good Interpretation). Brno: Partnership Foundation.

Ptáček, L. (2004). Interpretace mistniho dědictvi - Přiručka pro plánováni a tvorbu prezentaci mistnich zajimavosti (Local Heritage Interpretation - A Guide to Planning and Creating Presentations of Local Attractions). Brno: Partnership Foundation.

Raistrick, A. (1972). Industrial Archaeology: An Historical Survey. London: Eyre Methuen.

Schejbal, C. (2016). Montánní turismus (Mining tourism). Ostrava: Technical University of Ostrava. Smith, L. (2006). Archaeological Theory and the Politics of Cultural Heritage. London: Routledge. 
Stefanovová, Z., \& Lednický, V. (2012). Cestovní ruch a technické památky (Tourism and technical monuments). Ekonomika - Management - Inovace (Economy - Management - Innovation) 4(3) 58-67.

Štýs, S. (1990). Rekultivace územi devastovaných těžbou nerosti̊ (Reclamation of territories devastated by mining of minerals). Prague: SNTL.

Timothy, D., \& Boyd, S. (2003). Heritage Tourism. New York: Pearson Education.

Tomíšková, M. (2011). Průmyslové dědictví a cestovní ruch (Industrial Heritage and Tourism). Urbanismus a územni rozvoj (Urban Planning and Spatial Development), 14(3), $28-32$.

Urban, M. (2011). Výchozí bod Jáchymov (Starting point of Jachymov). In Urban et al. (Eds.), Tři studie k hornické a kulturni krajině českého Krušnohoři s výchozimi body Krupka, Hora svaté Kateřiny, Jáchymov. (Three studies on the Mining and Cultural Landscape of the Czech Ore Mountains with the starting points of Krupka, Mount of St. Catherine, Jachymov), (Study, Part 3). Most: Regional Museum in Most.

Urry, J. (1990). The Tourist Gaze: Leisure and Travel in Contemporary Societies. London: Sage.

Wheeler, R. (2014). Mining memories in a rural community: Landscape, temporality and place identity. Journal of Rural Studies, 36, 22-32. DOI: 10.1016/j.jrurstud.2014.06.005.

Wright, P. (1985). On Living in an Old Country: The National Past in Contemporary Britain. London and New York: Verso.

Zelenka, J., \& Pásková, M. (2002). Výkladový slovnik cestovniho ruchu (Interpreting Dictionary of Tourism). Prague: Ministry for Regional Development of the Czech Republic. 